explanation, for this absence of eggs has been remarked upon at many newly-formed fulmar colonies. It seems more likely that these early colonists are immature birds.

The flight of the fulmar petrel is so beautiful and inspiring a thing that it is pleasant to watch this increase in the species, but it must be admitted that other seafowl do not like the fulmar as a nesting neighbour, perhaps because of the strong smell of the birds and of their young.
To see the fulmar in its greatest numbers one must journey to the Arctic. In Spitsbergen it nests inland, laying its egg on icy ledges amid the eternal snows three thousand feet and more above sealevel. There is something uncanny in the passing, always in silence, of fulmars through a desolate snowy valley by the pale light of the midnight sun. The fulmar nests in Franz Josef Land and Novaya Zemlya and in Iceland, and also in Arctic America. In winter it ranges south to lat. $43^{\circ} \mathrm{N}$.

\title{
Physiological Bases of Nutrition
}

$\mathrm{O}$ $\mathrm{NE}$ of the outstanding developments of recent years has been the steady progress throughout the world of the idea that the State is responsible for the material well-being of its individual members. A liberal food supply has always been regarded as one of the essentials for material wellbeing. Until recently, however, it was not realised how far the attainment by an individual of good physique, vigorous health and freedom from disease, could be brought about by attention throughout the whole period of his life to certain qualitative aspects of his habitual diet. It is now becoming plain to many of the Governments of States that they cannot afford to leave out of consideration the provision for their populations of food of the kind which tends to promote health.

$\mathrm{It}$ is obviously no easy task to change the feeding habits of millions of people. The kinds of food considered desirable must be available in sufficient quantity and at reasonable prices before any considerable changes can be effected. It has therefore become a matter of no little political importance to investigate the possibility of planning local, imperial and world agricultural and economic policies which would enable a sufficient supply of the more desirable kinds of food to be produced, transported and marketed, to meet the nutritional requirements of the populations of the world.

Such investigations have already been undertaken on behalf of certain Governments, and for some years the Health Organisation of the League of Nations has been interested in problems of this kind. The Assembly of the League invited the Council last September to appoint a committee, including agricultural, economic and health experts, to submit a report on the whole question to the next Assembly. The Health Committee appointed without delay a panel of twelve health experts to report on the fundamental problem which would determine the action to be taken afterwards by the agricultural and economic experts, namely, the definition of the nutritional needs of the human being in the course of his development from conception to adult age.

The Health Experts met in London last Novem. ber, under the chairmanship of Prof. E. Mellanby, and have now issued their report*. This report is divided into two parts, the first dealing with the energy, protein and fat requirements, and the second with the mineral and vitamin requirements. The energy requirements are based on the calcula. tion that an adult, male or female, not engaged in manual work, needs 2,400 calories a day. Those engaged in work should receive extra calories based on the nature of the work and the length of time they are engaged in such work. These extra requirements range from 50 calories an hour for light work up to 200 calories or more for very hard work. The calorie needs of children can be calcu. lated from a table of coefficients giving the basic requirements, to which are to be added extra calories to meet the needs for muscular activities; such activities may be considered to be equivalent to light work in the case of boys and girls aged seven to eleven years and of girls aged eleven to fifteen years, and to be equivalent to moderate work in boys aged eleven to fifteen years. For nursing women a basic allowance of 3,000 calories is suggested.

The protein allowance for all adults should be at least 1 gram for every kilogram of body-weight, and it is considered desirable that part of it should be of animal origin. During growth, pregnancy and lactation, some animal protein is considered necessary, and in the growing period it should form a large proportion of the total protein. It is recommended that pregnant and nursing women should receive 2 grams of protein per kilogram of body-weight. It is not thought possible to define

* League of Nations. Health Organisation. Report on the Physiological Bases of Nutrition by the Technical Committec appointed by

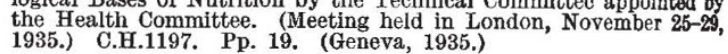


the quantity of fat to be included in the diet, though a certain amount ought to be present.

The section of the report dealing with mineral and vitamin requirements directs attention to the fact that modern diets are deficient in foods rich in minerals and vitamins, that is, protective foods, rather than in foods rich in calories. The protective foods include, first and most important, milk and milk products, eggs and glandular tissues; then green-leaf regetables, fruit, fat fish and meat (muscle). Among the energy-bearing foods of little or no protective power are sugar, milled cereals and certain refined fats. Pregnant and nursing women should be regarded as in greatest need of protection, and a dietary schedule has been drawn up to indicate how they may obtain adequate supplies of the necessary protective elements. This diet contains a litre of milk, eggs, cheese, potatoes and green vegetables. It is recommended that cod liver oil should be added except in sunny seasons and sunny countries.

Special attention has been given to diets suitable for infants and children up to the age of five years. The importance of breast feeding for nine months is urged. The diet after weaning should contain a litre of milk, eggs, green and root vegetables, cod liver oil and raw fruit or vegetable to supply vitamin $\mathrm{C}$.

Certain general recommendations are made to ensure that the average individual's diet contains a sufficiency of protective elements. Variety in diet tends to safety, though even a varied diet may be deficient in important elements. White flour is deprived of valuable food constituents, and its partial substitution by lightly milled cereals and by potatoes is recommended. The consumption of excessive amounts of sugar is condemned. Milk should form a conspicuous element of the diet at all ages. Fresh fruit and vegetables should always be constituents of the normal diet. By the inclusion in the diet of optimum amounts of the protective foods, adequate provision of all vitamins except vitamin $\mathrm{D}$ is readily accomplished.

This report represents the considered opinion of experts in the field of nutrition from Great Britain, the United States of America, France, Sweden, Norway and Russia. The universal adoption of their recommendations would require notable changes in agricultural and economic policies throughout the world, and it now remains for experts in these fields to consider how far it is possible to give practical effect to the recommendations.

S. J. C.

\section{Obituary}

Mr. P. C. Gilchrist, F.R.S.

$\mathrm{M}^{\mathrm{R}}$ R. PERCY CARLYLE GILCHRIST, who died on December 16, had for a long time lived in retirement, and was scarcely known to the present generation of metallurgists. Nearly sixty years ago, however, he was associated with the late Sidney Gilchrist Thomas, his cousin, in experiments which ultimately led to the establishment of the basic Bessemer process.

In 1855, Bessemer discovered that a stream of air when blown through molten pig iron removed its carbon and silicon by oxidation, the heat evolved being sufficient to retain the metal in a molten condition. The metal thus produced was brittle owing to its oxidised condition. A year later, Mushet made the important discovery that if manganese was added to the molten metal in the form of ferro-manganese, it removed this absorbed oxygen and enabled sound and malleable ingots to be cast. It so happened that in his early experiments Bessemer used Swedish pig iron which was low in phosphorus. These discoveries led to the establishment of the acid Bessemer process in which the lining of the converter is a siliceous refractory material. This was the beginning of the age of cheap steel. Any irons which had a suitable content of silicon and were low in phosphorus could be treated by this method; but phosphoric cast irons were not amenable to this treatment, since with an acid lining the phosphorus remains in the finished steel and renders it brittle.

In 1870 Sidney Gilchrist Thomas, at that time a junior clerk in the Metropolitan Police Force at a salary of $£ 90$ a year, attended a course of lectures at the Birkbeck Institute. For some years he had been devoting his spare time to the study of natural science and in particular of chemistry. At one of these lectures, Mr. George Challoner, the lecturer, said: "The man who eliminates phosphorus by means of the Bessemer converter will make his fortune". Thomas never forgot this, and from that time he became a constant reader of all the literature on the subject. In $\mathbf{1 8 7 2}$ he studied in the advanced course of mineralogy at the Royal School of Mines and obtained a first-class. In the following year he was awarded a first-class in the advanced course in inorganic chemistry. After some preliminary experiments, he enlisted the help of his cousin Percy Carlyle Gilchrist, who was then a chemist to certain works at Cwm Avon in South Wales. The original theory of the dephosphorisation process was due to Thomas. At the outset, Gilchrist was doubtful about it, but undertook to make some experiments. Both 